\title{
Response of Yield, Growth and Iron Deficiency Chlorosis of 'Santa Maria' Pear Trees on Four Rootstocks
}

\author{
Ali IKINCI ${ }^{1 *}$, Ibrahim BOLAT ${ }^{1}$, Sezai ERCISLI ${ }^{2}$, Ahmet ESITKEN $^{3}$ \\ ${ }^{1}$ Harran University, Faculty of Agriculture, Department of Horticulture, 63300 Sanliurfa, \\ Turkey; aliikinci@harran.edu.tr (*orrespondingauthor);ibolat@harran.edu.tr \\ ${ }^{2}$ Ataturk University, Faculty of Agriculture, Department of Horticulture, 25240 Erzurum, Turkey; sercisli@gmail.com \\ ${ }^{3}$ Selcuk University, Faculty of Agriculture, Department of Horticulture, Konya, Turkey; aesitken@selcuk.edu.tr
}

\begin{abstract}
This study was conducted on the 'Santa Maria' pear (Pyrus communis L.) budded on various rootstocks: pear seedling (Pyrus communis L.) and three quince (Cydonia oblonga Mill.) rootstocks, respectively 'BA 29', 'QA' and 'QC', under calcareous soil and semi-arid conditions, during 2004-2012. The results showed that the highest cumulative yield per ha (53.1 t $\left.\mathrm{ha}^{-1}\right)$, fruit weight $(304.1 \mathrm{~g})$, fruit volume $\left(337.2 \mathrm{~cm}^{3}\right)$, fruit flesh firmness $(22.3 \mathrm{lb}$.) and titratable acidity $(0.21 \%)$ was obtained from trees on 'BA 29 ' rootstock. The highest soluble solids content $(15.8 \%)$, cumulative yield per tree $\left(78.08 \mathrm{~kg}^{-1}\right.$ tre $\left.^{-1}\right)$, trunk cross sectional area $\left(79.03 \mathrm{~cm}^{2}\right)$ and the lowest titratable acidity $(0.18 \%)$ were obtained from pear seedling. The most vigorous trees were grown on pear seedling, followed by 'BA 29', 'QA' and 'QC' rootstocks. The 'Santa Maria' pear variety's leaf chlorophyll content on all rootstocks fell during the study period up to $60 \mathrm{DAFB}$ compared with $30 \mathrm{DAFB}$. It was found that leaf chlorophyll and Fe contents were higher in trees on pear seedling and 'BA 29' rootstocks and lower in those on 'QA'.
\end{abstract}

Keywords: Pyrus communis, Cydonia oblonga, pear rootstocks, Fe chlorosis, chlorophyll content, 'BA 29', quince C Abbreviations: DAFB - days after full blooming; SSC - soluble solids content; TCSA - trunk cross sectional area

\section{Introduction}

In respect of a rootstock adapted to different soil conditions is not sufficient knowledge in pear culture. Pyrus and quince rootstocks have their advantages and disadvantages. In each case, site-specific ecological characteristics, specific cultivar response, and production objectives must be considered before deciding on the best strategy (Lombard and Westwood, 1987; Masseron, 1989; Stern and Doron, 2009). In Europe, significant developments have been achieved in precocity, yield efficiency and quality since pear seedlings were replaced with 'QA', 'QC' and 'BA 29' clonal quince (Cydonia oblonga) rootstocks (Westwood, 1993; Iglesias and Asin, 2005). In many contemporary pear orchards in Turkey, saplings budded on clonal quince rootstock are preferred. The most commonly used rootstock in these orchards is 'QA'. Believed to produce more dwarfing than 'QA', the rootstock of ' $\mathrm{QC}$ ' is preferred, especially in orchards that are planted more densely. 'QA' has been found to be less powerful than the rootstock of 'BA 29' which is preferred because it tolerates heavy clay, wet soil, provides earliness like other rootstocks, and for its yield efficiency. Nevertheless, most Turkish soils have an alkaline reaction and approximately $85 \%$ of soil have $\mathrm{pH}$ value over 7.0
(Ulgen and Yurtsever, 1995), and in a large part of the peargrowing areas has also high $\mathrm{CaCO}_{3}$ content in Turkey and lime-induced Fe chlorosis widely appears in these orchards. So, there is little information available concerning the rootstock usage in pear cultivation under calcareous soils and semi-arid climate conditions.

The high lime content of soil is one of the important problems which effect to soil fertility. Calcareous soils cover more than $30 \%$ of the earth's land surface (Faust, 1989). This is a widespread and damaging nutritional disorder in several important horticultural crops (Wertheim and Webster, 2005). In general, horticultural crops such as pear, peach and grape are also considerably sensitive to lime-induced chlorosis. Limeinduced iron chlorosis is a term often used for chlorosis associated with disturbed $\mathrm{Fe}$ metabolism on high $\mathrm{Ca}$ containing soil (Faust, 1989). These soils are frequently characterized by the low availability of plant nutrients like Fe, $\mathrm{Mn}, \mathrm{Cu}$ and $\mathrm{Zn}$ due to their poor solubility at high $\mathrm{pHs}$ (Marschner and Römheld, 1995). Thus, lime-induced Fe chlorosis can be a great problem in calcareous soils. Chlorosis due to the unavailability of $\mathrm{Fe}$ in calcareous soils with a high $\mathrm{pH}$ is a major agricultural problem that results in reduced crop yields which are estimated about $1 / 3$ of cultivated soils 
564

worldwide (Wallace and Lunt, 1960). In which case, significant reductions occur in plant growth, development, and yield. Fe chlorosis reduces fruit bearing and fruit quality and affects tree growth. Additionally, it delays fruit maturation and increases orchard care costs (Tagliavini and Rombolá, 2001).

The disorder can be controlled by supplying extra iron to the trees through soil applications, trunk injections or foliar sprays, but these measures are costly and the effects are only temporary (Wertheim and Webster, 2005). It is suggested that the most suitable resolution to prevent iron chlorosis is to use Fe chlorosis resistant genotypes as rootstocks. Quince rootstocks prefer more than $P$. communis rootstocks in pear growing. However, quince rootstocks compared with pear seedlings enhance pear scion susceptibility to lime-induced Fe chlorosis. Clonal quince rootstocks used in pear cultivation bring along advantages and disadvantages as seedlings do. Consequently, the appropriate scion/rootstock component should be known while planning strategies for pear cultivation in a region with specific ecological conditions.

Therefore, this study was conducted to determine the suitable pear cultivars and rootstock components in order to expand pear cultivation in semi-arid and calcareous soil conditions such as southeastern Turkey. In this study, the performance of the Santa Maria pear variety on seedling and several clonal rootstocks was assessed under calcareous soil conditions.

\section{Materials and Methods}

\section{Plant material and experimental conditions}

This study was conducted between 2004 and 2012 at the Pome Fruit Research Station of the Faculty of Agriculture at Harran University (Sanliurfa, Turkey). Research garden is located east of Sanliurfa province and is $25 \mathrm{~km}$ from the city center $\left(37^{\circ} 19^{\prime} \mathrm{N}\right.$ and $38^{\circ} 96^{\prime} \mathrm{E}$; altitude: $530 \mathrm{~m}$ ) (Google Earth, 2016). Sanliurfa province has continental climate features; it is cold and wet in the winter and very hot and dry in the summer. The weather is hot and dry from May to October, when temperatures can reach up to $46^{\circ} \mathrm{C}$, and is usually warm during the winter (Fig. 1). During the experiment, the air temperatures were in average $29.6^{\circ} \mathrm{C}$ in summer and $6.4^{\circ} \mathrm{C}$ in winter, while annual precipitation ranged between 428-486 $\mathrm{mm}$, mainly concentrated between the months of November and April. The average relative humidity is at the level of $51 \%$. Relative humidity is the highest (69\%) ratio in January, in July is the lowest (33\%) level.

The soil in the orchard $(0-40 \mathrm{~cm})$ is loamy with $40 \%$ clay, $33.2 \%$ silt, $21.4 \%$ sand, poor in organic matter $(1.1 \%)$, rich in calcium carbonate content (25\%), and has a high $\mathrm{pH}(8.4)$ and a low content of available Fe (DTPA-extractable Fe: $1.45 \mathrm{mg}$ $\mathrm{kg}^{-1}$ ) (Anonymous, 2012).

Experiments were carried out on "Santa Maria" pear variety and on pear seedling (Pyrus communis L.), 'QA', 'QC' and 'BA 29' quince (Cydonia oblonga Mill.) rootstocks. The research plantation was established in December 2004. Trees on pear seedling rootstocks were planted at $5 \mathrm{~m} \times 5 \mathrm{~m}$ (400 trees ha $\left.{ }^{-1}\right)$ and trees on the $C$. oblonga variety rootstocks were planted at 5 $\mathrm{m} \times 2.5 \mathrm{~m}\left(800\right.$ trees $\left.^{\mathrm{h}} \mathrm{a}^{-1}\right)$ distance and trained as a central leader system.

Trees were drip irrigated. Drip irrigation pipes with 0.40 $\mathrm{cm}$ dripper nozzles and a total length of $5 \mathrm{~cm}$ were placed as pigtail around the trees. Irrigation of the orchard was carried out using a computerized drip irrigation system. Irrigation amounts were according to regional recommendations using class A pan. Trial trees were fertilized using the fertigation method. Soil, pest and disease management were carried out according to the rules of integrated plant protection.

Yield effects of rootstocks were evaluated by yield per tree $\left(\mathrm{kg} \mathrm{tree}^{-1}\right)$ and cumulative yield $\left(\mathrm{kg} \mathrm{tree}^{-1}\right.$ and tons ha $\left.{ }^{-1}\right)$ in 20082012 , and yield efficiency $\left(\mathrm{kg} \mathrm{cm}^{-2}\right)$ in 2012. For calculating the trunk cross-sectional area (TCSA), trunk circumference about $20 \mathrm{~cm}$ above the graft union was measured with a hand caliper at the end of the growing season and converted to TCSA in $\mathrm{cm}^{2}$. Finally, yield efficiency (yield per tree/TCSA) was measured as yield per tree divided to TCSA in the late growing season.

Additional investigations of internal and external fruit quality parameters were performed at harvest time in 20082012. For the analyses of fruit quality characteristics, the total fruit was graded according to size. Ten fruit from the bulk group were taken as a representative sample for further analyses. The important fruit traits such as individual fruit weight, fruit volume, SSC, acidity, flesh firmness etc. were measured. Fruit flesh firmness was measured on opposite sides of the fruit with skin removed by using fruit pressure tester (FT-327, TR Turoni, Forli, Italy) with $11 \mathrm{~mm}$ diameter probe and expressed in lb. The soluble solids content (SSC) (\%) was measured with a hand Atago refractometer. Titratable acidity of fruit juice was measured by titrating fruit juice against $0.1 \mathrm{~N} \mathrm{NaOH}$ at $\mathrm{pH} 8.1$ and was expressed as percent malic acid. In addition, the effect of rootstocks on chlorophyll index value and leaf Fe content was evaluated in 2010-2012.

\section{Leaf chlorophyll content detection}

The index of chlorophyll per leaf was measured with the FieldScout CM1000 Chlorophyll Meter (FieldScout Spectrum Technologies, Inc.). The chlorophyll measurement was taken between 2010 and 2012, 30 and 60 days after the full bloom, according to Toselli et al. (2000). A total of 96 measurements were made on 48 fully developed, healthy leaves. Eight trees of each scion/rootstock component were sampled, and the measurement was taken upper fully expanded young healthy leaves. Low chlorophyll meter values correspond to the high degree of chlorosis.

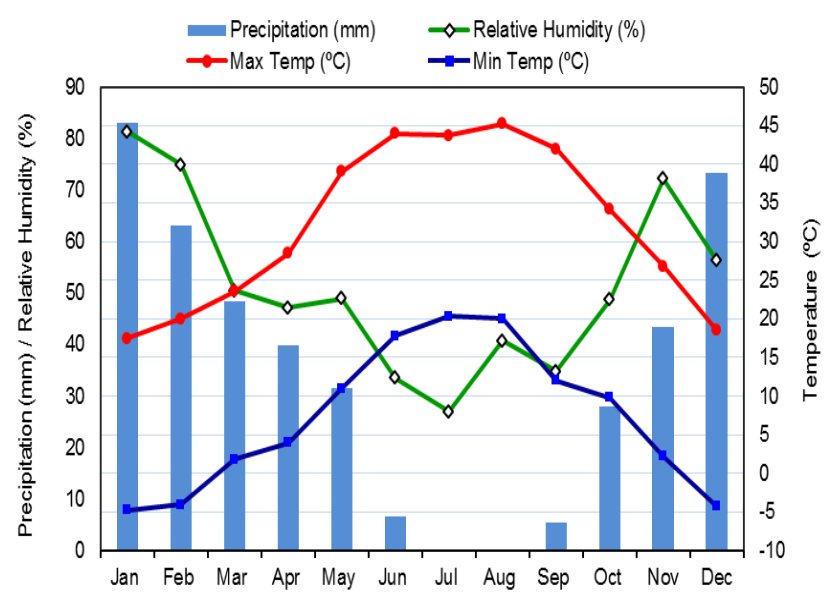

Fig. 1. Monthly temperature, rainfall and relative humidity for Sanliurfa during the time period 2004-2012 
Chlorosis of these leaves was also rated visually on 30 and 60 days after full bloom (DAFB) using a scale similar to that used by Shi and Byrne (1995) with $1=$ green leaves with no chlorosis; 2 =green leaves with slightly yellow interveinal areas; $3=$ most of the interveinal region is yellow, but veins are green; $4=$ entire interveinal region is distinctly yellow, veins are pale green to yellow, and $5=$ entire leaf is yellow to white.

\section{Iron content determination}

At 30 and 60 DAFB, after FieldScout CM1000 chlorophyll meter measurements, the leaves were collected and then washed using a solution containing $0.1 \%$ Teepol detergent in $0.1 \mathrm{M} \mathrm{HCl}$ in order to remove dust particles and then in distilled water. The leaves were oven dried for 72 hours at $65^{\circ} \mathrm{C}$, ground to powder and mineralized in $1 \mathrm{M} \mathrm{HNO}_{3}$ and analyzed for total Fe concentration according to Kacar and Inal (2008) using by atomic absorption spectrophotometry. Leaf Fe content was reported as $\mathrm{mg} \mathrm{kg}^{-1}$ of DW.

\section{Statistical analyses}

Data were evaluated by analysis of variance with Minitab 16.1.0 Statistics software package. When the F- test was significant, means were separated by Duncan's multiple range test $(\mathrm{P} \leq 0.05)$.

\section{Results and Discussion}

\section{Tree size}

It was found that there were significant differences between the trunk cross-sectional areas (TCSA) of trees on rootstocks (Fig. 2). Until the end of 2008, trees on all rootstocks had similar TCSA's with no significant differences between them, and increasing rate of TCSA was slow, but hereafter TCSA increase was fast, especially in trees on the seedling. However, as from 2008, the differences started to be significant chiefly between seedling and quince rootstocks. In all measuring time, the highest TCSA was found in trees on pear seedling followed by 'BA 29', and TCSA of 'Santa Maria' trees on rootstocks was ranked as seedling > BA 29'> 'QA'> 'QC'.

In general, it was observed in our study that the TCSA growths of vigorous rootstocks were more than dwarfing ones. These results are in accordance with a number of studies, which show that Cydonia oblonga rootstocks such as 'QA', 'QC' and 'BA 29' are dwarfing or semi-dwarfing compared with the Pyrus communis rootstocks such as seedling and OHF (Westwood, 1993; Hirst and Flowers, 2000; Webster, 2003, Iglesias and Asin, 2005; Wertheim and Webster, 2005). In fact, in a study comparing OHF series rootstocks with 'BA 29' rootstock, the lowest diameter growth of the 'Red Bartlett' pear cultivar was found on the 'BA 29' rootstock (Kosina, 2003).

\section{Yield and fruit characteristics}

Five years of trials (2008-2012) showed that rootstocks including pear seedling, 'QA', 'QC' and 'BA 29' affected annual yield $\left(\mathrm{kg} \mathrm{tree}^{-1}\right)$, cumulative yields $\left(\mathrm{kg}\right.$ tree ${ }^{-1}$ and tons $\left.\mathrm{ha}^{-1}\right)$, and cumulative yield efficiency $\left(\mathrm{kg} \mathrm{cm}^{-2}\right)$. In some trees, the first fruit set occurred in 2006 and 2007 . These fruits were excluded from the fruit yield measurements as they were very small and few. No significant difference was found among yields of pear trees budded on seedling and three different $C$. oblonga rootstocks within the 2008 to 2009 period. Significant differences related to yield were found between rootstocks starting from the seventh year. In 2010, the results showed that yield significantly increase on seedling compared with the other rootstocks. In 2011, no significant differences among seedling, 'BA 29' and 'QC' were observed, but 'QA' was very low. In 2012, seedling and 'BA 29' gave a significantly higher yield than 'QA' and 'QC'.

'Santa Maria' on the pear seedling gave the highest cumulative yield per tree $\left(\mathrm{kg}\right.$ tree $\left.^{-1}\right)$ while the 'QA' rootstock had a lower. However, according to cumulative yield per hectare (ton ha $\mathrm{h}^{-1}$ ), the highest and lowest cumulative yields were attributed to 'BA 29' and seedling, respectively. Furthermore, cumulative yield efficiency was significantly affected by rootstocks. The highest cumulative yield efficiency was obtained from 'QC' $\left(1.18 \mathrm{~kg} \mathrm{~cm}^{-2}\right)$ followed by 'BA 29 ' $\left(1.05 \mathrm{~kg} \mathrm{~cm}^{-2}\right)$.

Yields of trees on the three quince rootstocks were the lowest compared to the seedling. It is well known that tree size and cumulative yield per tree were positively correlated (Stern and Doron, 2009). However, for scion/rootstock trials, the cumulative value per tree may not be an accurate indicator of rootstocks real performance. So, cumulative yields per ha were the highest trees on dwarfing rootstocks. It is also well known that tree size and yield per unit land area were negatively correlated (Wertheim and Webster, 2005). In addition, cumulative yield efficiency was higher trees on dwarfing rootstocks, except 'QA' than on seedling under calcareous soil and semi-arid conditions. It seems a fairly general rule that trees on dwarfing rootstocks produce more fruit per unit of growth (Wertheim and Webster, 2005). As a matter of fact, Kappel and Quamme (1988) reported that the lowest TCSA $\left(\mathrm{cm}^{2}\right)$ and cumulative yield efficiency ( $\mathrm{kg} / \mathrm{tree})$ values were found in the 'Harvest Queen' cultivar on 'QA'. In addition, Kosina (2003) obtained the highest yield efficiency of the 'Red Bartlett' on 'BA 29'.

The average values of selected some fruit characteristics of the Santa Maria pear variety grafted on different rootstocks between the fifth and ninth years are presented in Fig.3 and Table 2. It was found that rootstocks effects on 'Santa Maria' pear cultivar of average fruit flesh firmness (lb.) were not statistically significant while significance was found in average

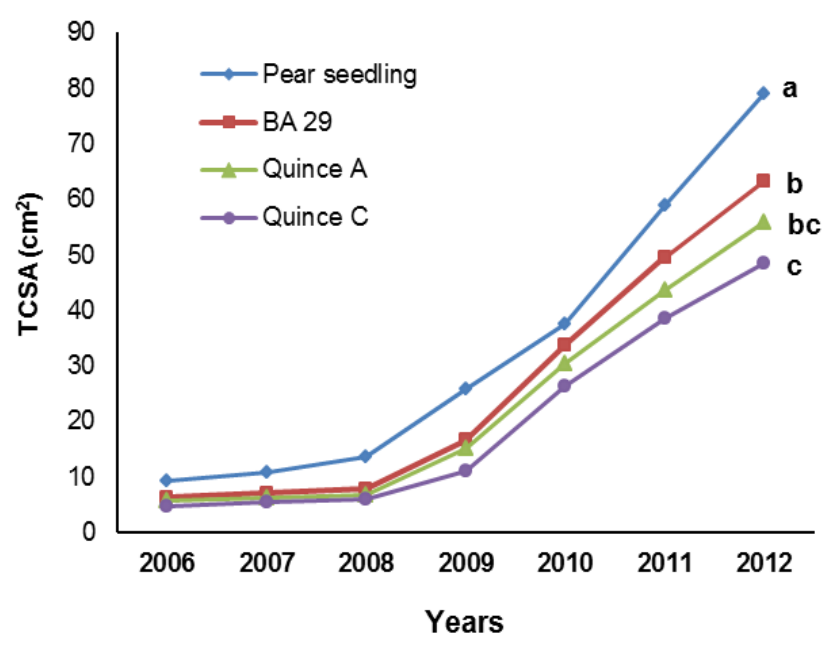

Fig. 2. TCSA increase of the Santa Maria pear trees on some rootstocks between 2006 and $2012(P<0.05)$ 
Table 1. Annual yield, cumulative yield and cumulative yield efficiency in 2012 of 'Santa Maria' pear, as influenced by rootstock

\begin{tabular}{|c|c|c|c|c|c|c|c|c|}
\hline \multirow{2}{*}{ Rootstocks } & \multicolumn{5}{|c|}{ Annual yield (kg tree $\left.{ }^{-1}\right)$} & \multirow{2}{*}{$\begin{array}{l}\text { Cumulative yield } \\
\qquad\left(\mathrm{kg} \mathrm{tree}^{-1}\right)\end{array}$} & \multirow{2}{*}{$\begin{array}{l}\text { Cumulative yield } \\
\left(\text { tons } \mathrm{ha}^{-1}\right)\end{array}$} & \multirow{2}{*}{$\begin{array}{c}\text { Cumulative yield } \\
\text { efficiency } \\
\left(\mathrm{kg} \mathrm{cm}^{-2}\right)\end{array}$} \\
\hline & 2008 & 2009 & 2010 & 2011 & 2012 & & & \\
\hline Pear seedling & 3.90 & 7.42 & $16.26 \mathrm{a}$ & $22.95 a$ & $27.48 \mathrm{a}$ & $78.02 \mathrm{a}$ & $31.20 \mathrm{~b}$ & $0.99 c$ \\
\hline 'BA 29' & 4.39 & 8.04 & $10.08 \mathrm{~b}$ & $20.90 \mathrm{a}$ & $22.96 \mathrm{ab}$ & $66.38 \mathrm{~b}$ & $53.10 \mathrm{a}$ & $1.05 \mathrm{~b}$ \\
\hline 'QA' & 3.45 & 5.86 & $8.48 \mathrm{c}$ & $13.52 \mathrm{c}$ & $18.14 b$ & $49.44 \mathrm{c}$ & $39.55 \mathrm{ab}$ & $0.89 \mathrm{~d}$ \\
\hline 'QC' & 4.91 & 7.53 & $8.59 \mathrm{c}$ & $18.44 \mathrm{ab}$ & $17.82 \mathrm{~b}$ & $57.29 \mathrm{~b}$ & $45.83 \mathrm{ab}$ & $1.18 \mathrm{a}$ \\
\hline
\end{tabular}

Means followed by different letters on the same column are significantly different according to Duncan's multiple range test at $\mathrm{P}<0.05$.

Table 3. Chlorophyll index value, leaf Fe content and visual chlorosis rates of the Santa Maria pear growing on various rootstocks (averages from 2010-2012)

\begin{tabular}{ccccc}
\hline \multirow{2}{*}{ Rootstocks } & \multicolumn{2}{c}{30 DAFB } & \multicolumn{2}{c}{60 DAFB } \\
\cline { 2 - 4 } & $\begin{array}{c}\text { Chlorophyll Index } \\
\text { Value }\end{array}$ & Leaf Fe content $\left(\mathrm{mg} \mathrm{kg}^{-1}\right)$ & $\begin{array}{c}\text { Chlorophyll Index } \\
\text { Value }\end{array}$ & Leaf Fe content $\left(\mathrm{mg} \mathrm{kg}^{-1}\right)$ \\
\hline Pear seedling & 101.73 & $71.50 \mathrm{a}$ & $90.73 \mathrm{a}$ & $60.98 \mathrm{a}$ \\
'BA 29' & 95.50 & $68.41 \mathrm{~b}$ & $86.41 \mathrm{a}$ & $60.46 \mathrm{a}$ \\
'QA' & 86.23 & $57.17 \mathrm{~d}$ & $73.39 \mathrm{~b}$ & $2.8 \mathrm{~b}$ \\
'QC' & 88.30 & $64.15 \mathrm{c}$ & $77.88 \mathrm{~b}$ & $3.9 \mathrm{a}$ \\
\hline
\end{tabular}

Means followed by different letters on the same column are significantly different according to Duncan's multiple range test at $\mathrm{P}<0.05$.

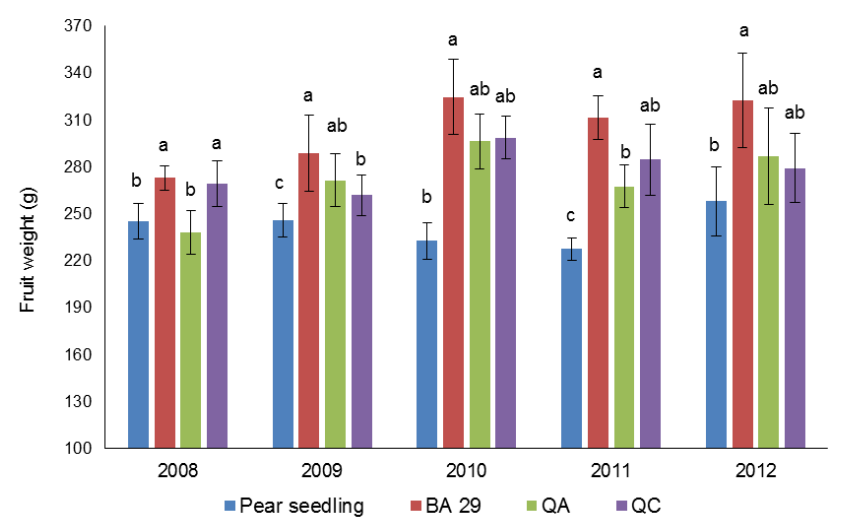

Fig. 3. The effect of four rootstocks at Sanliurfa on average fruit weight of 'Santa Maria' between 2008 and $2012(p<0.05)$

fruit weight $(\mathrm{g})$, average fruit volume, soluble solid content (SSC) and titratable acidity (TA).

Wertheim and Webster (2005) reported that rootstocks have only a minor effect on fruit quality in temperate-zone fruit species. However, they also mentioned that in pear, rootstock effects on fruit size could occur and some Pyrus rootstocks might induce small fruit size. In fact, although to be not statistically significant pear seedling produce smaller fruit than quince rootstocks in our study. Some fruit properties such as fruit volume and SSC were affected by rootstocks in our study. These effects may be from yield variations of rootstocks. As a matter of fact, Wertheim and Webster (2005) notified that possible rootstock effects on fruit properties can often be indirect and influenced by yield efficiency.

\section{Leaf chlorophyll and iron content}

Rootstocks also significantly affected leaf chlorophyll index value, leaf Fe content and a visual score of chlorosis (Table 3). According to averages collected in 2010-2012, no significant difference was found between leaf chlorophyll indexes values of trees on all rootstocks in the $30 \mathrm{DAFB}$. On the other hand in the $60 \mathrm{DAFB}$, it was found that trees on pear seedling and 'BA 29' rootstocks had the highest leaf chlorophyll index values.
Table 2. Some pomological characteristics of "Santa Maria" fruit, as influenced by rootstocks (2008-2012)

\begin{tabular}{ccccc}
\hline Rootstock & $\begin{array}{c}\text { Fruit } \\
\text { volume } \\
(\mathrm{cm} 3)\end{array}$ & $\begin{array}{c}\text { Fruit flesh } \\
\text { firmness }(\mathrm{lb} .)\end{array}$ & $\begin{array}{c}\text { SSC } \\
(\%)\end{array}$ & $\begin{array}{c}\text { TA } \\
(\%)\end{array}$ \\
\hline Pear seedling & $262.92 \mathrm{c}$ & 19.76 & $15.80 \mathrm{a}$ & $0.18 \mathrm{~b}$ \\
'BA 29' & $337.16 \mathrm{a}$ & 22.33 & $14.68 \mathrm{~b}$ & $0.21 \mathrm{a}$ \\
'QA' & $271.90 \mathrm{bc}$ & 20.53 & $15.15 \mathrm{~b}$ & $0.19 \mathrm{ab}$ \\
'QC' & $276.60 \mathrm{~b}$ & 19.90 & $15.70 \mathrm{ab}$ & $0.19 \mathrm{ab}$ \\
\hline Means followed by different letters on the same column are significantly different
\end{tabular}

according to Duncan's multiple range test at $\mathrm{P}<0.05$.

Furthermore, those on ' $\mathrm{QA}$ ' and ' $\mathrm{QC}$ ' had the lowest chlorophyll index values (Table 3).

Significant differences were found among Fe contents of pear tree leaves on the rootstocks in the $30 \mathrm{DAFB}$ and 60 DAFB (Table 3). It was observed that the leaf Fe content determined in both periods was similar to leaf chlorophyll index values. In terms of the leaf Fe content, the highest value in the $30 \mathrm{DAFB}$ and $60 \mathrm{DAFB}$ was found in trees on pear seedling followed by trees on 'BA 29'. Trees on 'QA' rootstock had the lowest Fe content in both periods.

Chlorosis of Santa Maria tree leaves was assessed by visual scoring according to the method developed by Shi and Byrne (1995). In visual scoring, it was observed that trees with the greenest leaves were on pear seedling; leaves on 'BA 29' rootstock followed. It was found that the chlorosis rate of tree leaves on 'QA' was higher compared to 'QC'; however, the difference was not found to be significant.

In the present study, the Fe content of Santa Maria pear leaves on pear seedling was the highest and 'BA 29' rootstock followed thereafter. The lowest value was obtained from 'QA'. Pear is more tolerant to chlorosis than quince, while the 'BA 29' clone is more tolerant than the 'QA' clone (Tagliavini and Rombolá, 2001; Iglesias et al., 2004; Iglesias and Asin, 2005; Alcantara et al., 2012). In the 60 DAFB, no significant differences in terms of leaf $\mathrm{Fe}$ content and visual chlorosis rating were found between pear seedling and 'BA 29'. This situation could also be explained by tree size. Tagliavini $e t$ al. (2000) reported that Fe nutrition in trees is related to their size and distance of Fe transport. 


\section{Conclusions}

In calcareous soil and semi-arid climate conditions, if 'Santa Maria' pear variety is established in normal planting density, pear seedling should be recommended; if the planting is dense, 'BA 29' should be recommended.

\section{References}

Alcantara E, Montilla I, Ramirez P, Garcia-Molina P, Romera FJ (2012). Evaluation of quince clones for tolerance to iron chlorosis on calcareous soil under field conditions. Scientia Horticulturae 138:50-54.

Anonymous (2012). Egirdir Fruit Research Station Manager, Soil analysis results report.

Faust M (1989). Physiology of temperate zone fruit trees. John Wiley \& Sons, Inc. New York, USA.

Google Earth (2016). Google Earth (Version 7.1.5.1557) Osmanbey Campus, Harran University, Şanliurfa, Turkey. $37^{\circ} 10^{\prime} 56.76^{\prime \prime} \mathrm{N}, 38^{\circ} 59^{\prime}$ 22.64" E, Eye alt 1.06 km. Image@ 2016 DigitalGlobe. Retrieved 2016 May 29 from http://www.google.com/earth/index.html.

Hirst PM, Flowers RR (2000). Rootstock effects on growth and cell size of 'Gala' apple fruit. Acta Horticulturae 517:189-194.

Iglesias I, Asin L (2005). Performance of 'Conference' pear on self-rooted trees and several Old-Home X Farmingdale, seedling and quince rootstocks in Spain. Acta Horticulturae 671:485-491.

Iglesias I, Asin L, Montserrat R, Vilardell P, Carbo J (2004). Performance of some pear rootstocks in Lleida and Girona (Catalonia, NE-Spain). Acta Horticulturae 658:159-165.

Kacar B, Inal A (2008). Bitki analizleri. Nobel Yayın Dagitim Ltd. Sti., Ankara.

Kappel F, Quamme HA (1988). Growth and yield of pear cultivars on several rootstocks. Canadian Journal of PlantScience 68:1177-1183.

Kosina J (2003). Evaluation of pear rootstocks in an orchard. Horticultural Science 30:56-58.

Lombard PB, Westwood MN (1987). Pear rootstocks. In: Rom RC, Carlson RF (Eds). Rootstocks for fruit crops. Wiley-Interscience Publication, John Wiley \& Sons, Inc. New York, USA pp 145-183.
Marschner H, RömheldV (1995). Strategies of plants for acquisition of iron. Iron nutrition in soils and plants. Developments in Plant and Soil Sciences 59:375-388.

Masseron A (1989). Les porte-greffe pommier, poirier et nashi. [Apple, pear and nashi rootstocks]. Centre technique interprofessionnel des fruits et légumes, Paris.

Shi Y, Byrne DH (1995). Tolerance of prunus rootstocks to potassium carbonate-induced chlorosis. The Journal of the American Society for Horticultural Science 120:283-285.

Stern RA, Doron I (2009). Performance of 'Coscia' pear (Pyrus communis) on nine rootstocks in the north of Israel. Scientia Horticulturae 119:252-256.

Tagiavini M, Abadia J, Rombola AD, Abadia A, Tsipouridis C, Marangoni $\mathrm{B}$ (2000). Agronomic means for the control of iron deficiency chlorosis in deciduous fruit trees. Journal of Plant Nutrition 23:2007-2022.

Tagliavini M, Rombola AD (2001). Iron deficiency and chlorosis in orchard and vineyard ecosystems: A review. European Journal of Agronomy 15:71-92.

Toselli M, Marangoni B, Tagliavini M (2000). Iron content in vegetative and reproductive organs of nectarine trees in calcareous soils during the development of chlorosis. European Journal of Agronomy 13:279-286.

Ulgen N, Yurtsever N, 1995. Türkiye Gübre ve Gübreleme Rehberi [Fertilizer and fertilization guide of Turkey]. Republic of Turkey Prime Ministry, General Directorate of Rural Services, Soil and Fertilizer Research Institute Publications, General Publication No: 209, Technical Publications No: T.66,230p, Ankara.

Wallace A, Lunt OR (1960). Iron chlorosis in horticultural plants. A review. Proceedings of the Society for Horticultural Science75:819-841.

Wertheim S J, Webster AD (2005). Rootstocks and interstems. In: Tromp J, Webster AD, Wertheim SJ (Eds). Fundamentals of temperate zone tree fruit production, Buckhuys Publication, Leiden pp 156-175.

Westwoood MN (1993). Temperate-zone pomology: physiology and culture. Timber Press, Portland, Oregon. 